\title{
The Pre- and Posteruptive Effects of Fluoride in the Caries Decline
}

\author{
Eugenio D. Beltran, DDS, MPH \\ Brian A. Burt, BDS, MPH, PhD \\ Program in Dental Public Health \\ School of Public Health \\ The University of Michigan \\ Ann Arbor, Mł 48109-2029
}

Table 1 constitute the bulk of the evidence for the caries decline in economically developed countries.

The beginning of the caries decline cannot be specified precisely, though it may have been before the 1970 s $(13,14)$. Nor can the reasons for the decline be stated with certainty; many diseases have surged and declined throughout history for unknown reasons (15). Some specific causes that have been suggested, though with supporting evidence that is not always compelling, include decline in consumption of sugars, widespread use of antibiotics, improved vitamin and mineral consumption, and improved dental care. Other potential causative factors, though they cannot be documented, include bacterial and immunological changes. The reason most often suggested for the caries decline is the widespread use of fluoride. Water fluoridation reportedly is practiced to some extent in over 30 countries since it began in 1945 (16), fluoride toothpastes became a major component of the toothpaste market during the 1970s (17), and dentists around the world have been dispensing fluoride supplements and mouthrinses for years.

Water fluoridation was the original public health application of fluoride, and it remains the most contentious. There have long been divergent views on whether water fluoridation prevents caries primarily through preeruptive systemic uptake by developing enamel, or by posteruptive remineralization and various antibacterial effects $(18,19)$. The issue is worth exploring further, since better understanding of its mode of action will influence public policy and recommended use of all forms of fluoride. This article reviews the evidence relating to fluoride's preeruptive and posteruptive effects on dental enamel, and suggests hypotheses to explain why frequent fluoride exposure is a primary cause of the continuing decline in caries among children in countries where it is in common use.

\section{Early Studies}

Reports of the initial fluoridation field trials included little discussion about the mechanism by which fluoride acted, but it was implied that fluoridation was effective principally because fluoride was incorporated into developing enamel to form a "stronger" or "more acid-resistant" fluorapatite crystal $(20,21)$. In 1952, re-

\begin{abstract}
Send correspondence and reprint requests to Dr. Beltran. This study was supported by a contract from the Dental Disease Prevention Activity, Centers for Disease Control, Atlanta, Georgia. Manuscript received: 12/29/87; returned to author for revision: 2/26/88; accepted for publication: $4 / 20 / 88$.

Introduction during the mid-1970s $(1,2)$, a series of reports contries soon after (3-12). The global nature of the decine was documented at the First International Conference Forsyth Dental Center, Boston, the proceedings of which were published as a special issue of the Journal of Dental Research in November 1982. The reports listed in
\end{abstract}


TABLE 1

Selection of Reports Since 1979 Describing Reductions in Caries Among Children in Different Countries (Field Trials of Water Fluoridation Not Included)

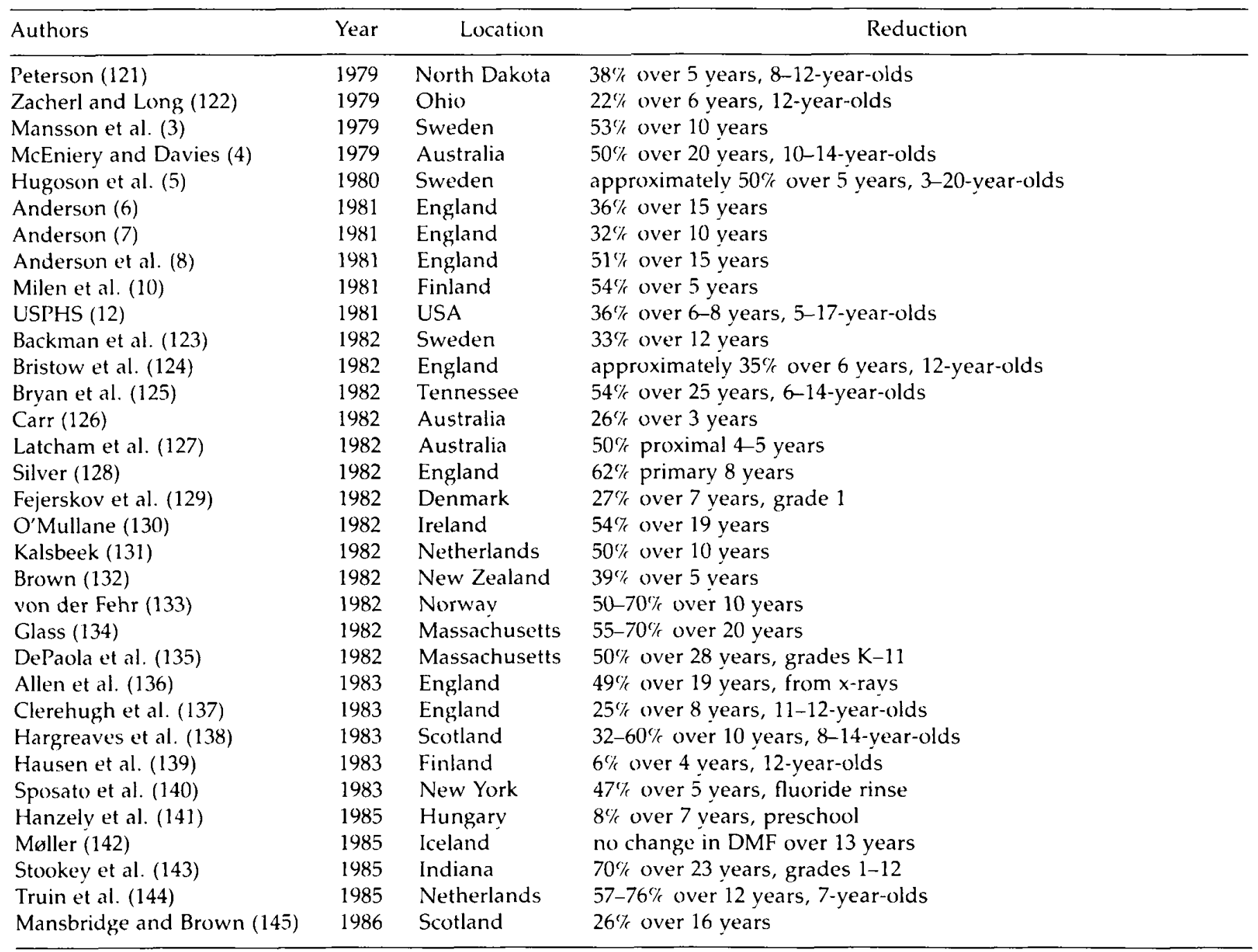

duction of enamel solubility was listed as the first of four theories on how fluoridation prevented caries, and a nonspecified topical action was the fourth (22). This view probably reflected the extensive research into hydroxyapatite chemistry and crystallography that began during the 1940s. (The other two theories listed were salivary action and inhibition of bacterial and enzymatic processes.) Even with applications of high-concentration topical solutions, early studies were interpreted as showing that the fluoride was incorporated into enamel as fluorapatite with only a small amount forming calcium fluoride on the enamel surface (23).

A natural corollary of the "stronger enamel" view was that full benefit from fluoridation came only when children were drinking fluoridated water from birth, thus receiving maximum preeruptive uptake during the period of tooth development (24). Even though a number of early reports showed that teeth already erupted benefited when fluoridation began (25-28), all concluded that the earlier that fluoridation began for each cohort, the greater the anticariogenic effect. In the dental literature from the 1940 s and early 1950s, the only questioning of whether action of fluoride resulted from preeruptive uptake was reported to have come from Volker in 1940 (22).

\section{Preeruptive Enamel Effects}

It was long assumed that maximum benefits from fluoridation were seen in the first cohort to consume fluoridated water from birth: "Children aged 5-8 years, with the use of fluoridated water from birth, apparentiy exhibit the ultimate degree of inhibition" (29). When evidence showed that fluoridated water benefited adults (30-32), the conclusion was that "fluoridation's benefits extend into adulthood." The dominance of the preeruptive view at the time is demonstrated by the design of these last three adult studies: all were restricted to permanent residents of the fluoridated areas, suggesting that the question of posteruptive benefits did not arise. 
Fluoride ingested prior to tooth eruption is partly incorporated into tooth enamel, mostly during the preeruptive maturation period (33). The amount of fluoride deposited preeruptively depends on its concentration in food, water, or supplements ingested (34), the duration of the ingestion period (35), and the length of the preeruptive maturation stage $(36,37)$. The principal benefits of preeruptive ingestion are considered to be improved crystallinity and reduced enamel solubility (38).

Apatite is typically a small, impure crystal, though fluoride effectively increases its crystallinity in bones and teeth (39). Improvement in crystallinity produces a thermodynamically more stable crystal that is more resistant to acid-dissolution, less impure, and possibly dimensionally bigger. In this regard, there is evidence that fluoride acts as a catalyst during mineralization, causing transformation of the more soluble precursors (octocalcium-, tricalcium-, and dicalcium phosphates) into a thermodynamically more stable apatite (40). It has also been suggested that fluoride might stabilize the apatite crystal through stronger hydrogen bonds $(41,42)$; an inverse carbonate-fluoride relationship in enamel has also been suggested (43-45).

\section{"There have long been divergent views on whether water fluoridation prevents caries primarily through preeruptive systemic uptake by developing enamel, or by posteruptive remineralization and various antibacterial effects."}

The presumed benefit from fluoride's reduction of enamel solubility is based on studies that reported higher concentrations in teeth from fluoridated as against nonfluoridated areas (46-50), and the in vitro observation that fluorapatite is less soluble than hydroxyapatite when exposed to acids (51-53). Several recent studies, however, have detected only slight differences in enamel fluoride concentration between fluoridated and nonfluoridated areas (54-56), and no differences could be detected between groups of Danish children who did or did not take fluoride supplements prior to tooth eruption (57). Earlier, it had been suggested that incorporation of fluoride only into the outermost layers of enamel was sufficient to permit all the enamel to behave as fluorapatite (58).

But even before these recent studies, it became apparent to some observers that a higher fluoride content of enamel could not by itself explain the considerable reductions in caries that fluoride brought about (59); the difference in enamel fluoride concentrations between fluoridated and nonfluoridated areas was simply insufficient. The theoretical concentration of fluoride in pure fluorapatite, which would produce a substantial reduction in acid solubility, is around $38,000 \mathrm{ppm}(38,59)$; but recorded values from an enamel depth of two microns are only in the order of $1,700 \mathrm{ppm}$ in nonfluoridated areas, 2,200-3,200 in 1 ppm fluoridated areas, and 4,800 $\mathrm{ppm}$ in an area with a water fluoride concentration of 5-7 ppm (60). These latter concentrations have also been found in the outermost enamel layers of people from low-fluoride areas (39).

If the elevated fluoride concentration in enamel from fluoridated areas is an important factor in caries prevention, then there should be a relation between enamel fluoride levels and caries experience. But results from a number of studies on this issue are contradictory. Significant but weak inverse relationships between surface enamel fluoride and DMF scores have been found among groups $(37,56,61-64)$, but not at the individual level $(63,65,66)$. A number of other studies, both in vivo and in vitro, have failed to demonstrate any relationship between enamel fluoride levels and caries experience in primary and permanent dentitions (67-73). Comparability of results from these studies is hampered by the different techniques employed for enamel biopsy, the variability in sample depths, and the different assumptions on calcium concentration in enamel and enamel density among the studies. Moreover, the fluoride concentration in the buccal surfaces of the incisors and premolars sampled for these studies may not represent fluoride concentration in the enamel of pits and fissures where caries usually begins.

Despite this equivocal relationship between enamel fluoride and DMF scores, some recent epidemiologic evidence joins the earlier studies to suggest that preeruptive fluoride effects are observable. Driscoll et al. (74), in their study of long-term benefits from supervised ingestion of fluoride supplements, found greater benefits to teeth that were unerupted at the time of the supplement program. In their study of children residing in a nonfluoridated areas, Burt et al. (75) found slightly less caries in permanent teeth among children who had previously lived for varying periods in fluoridated areas prior to eruption of the first molars.

\section{Posteruptive Enamel Effects}

As mentioned before, early fluoridation studies reported dental benefits to teeth that had already erupted at the time fluoridation began (25-28). Another study from this period found that children who moved to a fluoridated area prior to eruption of the first molars received the same benefits to the permanent teeth as did the original residents, regardless of the age at which the newcomers moved (76). Data from other studies indicated that continuing topical exposure to fluoride from drinking water was necessary to maintain anticaries effects $(77,78)$. While the results of Burt et al. (75) suggested a contrary effect, this latter study was in an age when toothpaste was a common source of continuing exposure to topical fluoride, whereas Russell's and the Antigo study were not. A British report from 1982 specifies clear benefits to teeth already erupted when fluoridation began (79), and recent Danish stud- 
ies also support posteruptive fluoride effects (80-83).

Although crystallinity improvement and decreased solubility are phenomena that occur both pre- and posteruptively (45), the major posteruptive effect of fluoride on dental enamel is remineralization of previously demineralized enamel $(38,59)$.

Remineralization has been defined by Arends and Gelhard (84) as "the deposition of mineral in enamel defects." Remineralization is a natural defense mechanism, as evidenced by human saliva's ability to promote remineralization by itself (85-87). Remineralization was concluded to be the cause of the arrest, or even the reversal, of early carious lesions in early fluoridation clinical trials $(88,89)$, as well as in lesions produced experimentally in vivo (90). Fluoride content of highly porous or previously "primed" enamel, such as that found in recently erupted enamel or white spot lesions, is much higher than that in adjacent sound enamel (9194). When teeth with such lesions are subjected to a slightly acidic environment, mineral dissolves from subsurface regions of the sound enamel, but not from the remineralized areas (95).

\section{"... a higher fluoride content of enamel could not by itself explain the considerable reductions in caries that fluoride brought about; the difference in enamel fluoride concentrations between fluoridated and nonfluoridat- ed areas was simply insufficient."}

Enhancement of this process, using both natural and artificial carious lesions, has been reported by several workers in vitro (96-103) and in vivo (84,104-108). The presence of fluoride in trace quantities is critical to the remineralization process $(49,97,101)$. If fluoride is present at the time of acid challenge, it will diffuse with the acid and inhibit dissolution at the crystal surface; if it is present during remineralization it enhances crystal growth and hence makes the overall remineralization process more rapid and effective (109). The source of the fluoride can be plaque fluid (110) or surface enamel.

Because remineralization is promoted by the frequent introduction of low-concentration fluoride into the oral environment (103), the small amount of fluoride in fluoridated drinking water is sufficient to promote remineralization. The requisite fluoride level can be obtained from fluoridated water at least as well as from other commonly used agents like toothpaste (38), though fluoride toothpaste is probably the main source of fluoride for remineralization in nonfluoridated areas (103). In fluoridated areas, fluoride from water supplies and from dentifrice may exert an additive effect, though this issue has received little epidemiologic study.
Where there is constant intake of low-concentration fluoride, from whatever source, the evidence suggests that a fluoride "reservoir" develops in plaque and remineralized subclinical lesions, from which fluoride is constantly being released in response to demineralization. The result is a continuing cycle of demineralization and subsequent remineralization to maintain enamel integrity. Only when demineralization overwhelms the defense mechanisms does clinical caries develop.

\section{Epidemiologic Studies}

If the principal (though not the sole) action of fluoride is posteruptive, then caries experience in communities with long-standing and comprehensive topical fluoride programs should, in time, approach that of communities where the drinking water is fluoridated. Data to suggest such a trend have been reported from Denmark (111) and from Canada (112). On the other hand, data from the 1979-80 National Dental Caries Prevalence Survey in the United States have been used to show that a considerable gap in caries experience still remains between fluoridated and nonfluoridated communities (113). These arguments are worth closer examination.

Thylstrup et al. (111) analyzed cross-sectional DMF data for the period 1972-80 from four areas of Denmark with differing concentrations of naturally occurring fluoride in the drinking water. Vordingborg $(1.2 \mathrm{ppm})$ is a stable rural community, while Ballerup $(0.4 \mathrm{ppm})$ and Hvidovre $(0.4 \mathrm{ppm})$ are rapidly growing suburbs of Copenhagen. Skibby $(0.5 \mathrm{ppm})$ is a small stable rural community in which the school dental service was established more recently than in the other communities. Thylstrup et al. found that DMF scores in fluoridated Vordingborg had declined only slightly over the 197280 period, while those from Ballerup and Hvidovre had declined sharply. DMF scores in Skibby declined moderately. The end result was that the initial 1972 gap in DMF scores between the fluoridated and nonfluoridated communities had been considerably narrowed, though DMF values were still a little lower in fluoridated Vordingborg. The authors concluded that the convergence of DMF scores was due to the generalized use of topical fluoride (toothpastes, rinses), both at home and through the school dental service.

Although this conclusion is plausible, the direct comparison between Vordingborg and the two suburban areas is hardly valid. The authors state that the population of each of the Copenhagen suburbs increased from around 20,000 in 1960 to about 50,000 at the time of writing. Assuming linear growth rates, this would mean about 50 percent growth in the period under study, 1972-80. In this sequential cross-sectional study, such rapid growth means that each suburb's apparent reduction in dental caries between 1972 and 1980 could have resulted as much from the influx of persons with excellent oral health as it did from improvements in the original residents. Thylstrup et al. (111) further argued that the posteruptive action of fluoride from toothpaste and from organized mouthrinsing programs makes wa- 
ter fluoridation unnecessary. That essentially political viewpoint invokes issues beyond the scope of this article, but the investigations presented no evidence to negate posteruptive effects from fluoride in drinking water.

In Canada, Johnston, Grainger, and Ryan (112) demonstrated that there was a marked caries decline in Ontario children in the 1972-84 period, and even suggested that it may have begun as early as the 1950s. They proposed that the widespread use of topical fluoride and water fluoridation, which reaches 72 percent of Ontario's population, as the most likely reasons for the decline. In Perth County, where 98 percent of the population drink water naturally fluoridated at optimum or above-optimum levels, the DMF for 13-yearolds fell from about 5.5 in 1972 to about 2.8 in 1984 (estimated from graph), this latter figure being still below the average for the province. The authors noted that caries declined by the same relative amount over time in fluoridated and in nonfluoridated areas. Like the report from Thylstrup et al. (111), this paper suggested nothing to oppose a posteruptive effect of fluoride from drinking water. Also as seen in the Danish report, caries experience was lower and continuing to decline in the fluoridated areas.

Brunelle et al. (113) used residential histories for children in the 1979-80 national survey in the United States to compare those with lifelong fluoridation ingestion against those with none. Children aged 5-17 who had received fluoridated water for their whole lives recorded 33 percent fewer DMFS lesions than those without fluoridated water. The magnitude of this difference is greater than that found in the Danish and Canadian studies; but since the potentially confounding effects of age-distribution and socioeconomic differences were not detailed (113), it cannot be taken too literally.

Regardless of the political point of view implied, these epidemiologic studies all indicate that the anticariogenic effects of fluoride continue over long periods of time. Some reasons for this phenomenon can now be hypothesized.

\section{Reasons for Continuing Anticaries Fluoride}

Action

There is no evidence that the caries decline has yet "bottomed out." If fluoride is largely responsible for the decline, this observation supports the view that its action continues beyond that to be expected solely from the results of short-term clinical trials, or even from the fluoridation field trials. Other reviewers have reached the same conclusion $(18,38,59)$.

One possible explanation is that fluoride is increasingly available from more sources, so that low-concentration fluoride is being introduced into the mouth more and more frequently from drinking water, toothpaste, mouthwashes, foods, and professional dental applications. Fluoride stored in surface enamel, plaque, and to some extent in saliva and on mucous membranes, is therefore always available when needed, meaning that remineralization is continually becoming more efficient.
In addition, more subtle changes in the ecology of the oral cavity may promote the continuing decline. Caries is a transmissible disease, with Streptococous mutans being transmitted to the mouths of infants soon after tooth eruption (114). Fluoride can interfere with this transmission by reducing $S$. mutans levels in mothers of infants, so that there are fewer bacteria to transmit $(115,116)$. In addition, low-concentration fluoride has been shown in vitro to induce $S$. mutuns to become less cariogenic through adaptation $(117,118)$. Some vears of widespread fluoride use in the economically developed world could have induced oral ecological change at a population level, and may be continuing to do so. The "hostile environment" for cariogenic bacteria created by widespread and long-term use of fluoride (119) mav now be the norm in many communities.

\section{"... low-concentration fluoride has \\ been shown in vitro to induce 5 . mutans to become less cariogenic through adaptation. Some years of wide- spread fluoride use in the economically developed world could have induced oral ecological change at a population level...."}

These hypothesized bacterial effects from low-concentration fluoride are more subtle and long-term than the direct bactericidal effects of high-concentration fluoride (120), and they could set up a compounding effect as time goes by; existing cariogenic bacteria diminish in cariogenicity, so less cariogenic bacteria are transmitted, then continuing use of fluoride reduces cariogenicity even further, and so on.

Either or both of the mechanisms described-i.e., more efficient remineralization or ecological changeare plausible explanations for why caries reductions have exceeded the levels to be expected from clinical trials, and why the anticaries effects of sustained fluoride use in a community are not maximized in the first cohort of children born after fluoridation begins.

\section{Conclusion}

The widespread availability of fluoride from various sources in developed countries has contributed to the reduction of dental caries in children. Water fluoridation and fluoride dentifrices are the major sources of continuous fluoride action within the oral cavity. While evidence supports both preeruptive and posteruptive fluoride effects, current research favors a greater role' for posteruptive fluoride. More efficient remineralization and ecological changes are both good reasons why fluoride induces continuing reductions in caries in countries where fluoride is widely used. 


\section{References}

1. Burt BA. Influences for change in the dental health status of populations; an historical perspective. J Public Health Dent 1978 Fall; $38: 272-88$.

2. Burt BA. The epidemiology of oral diseases. In: Striffler DF, Young WO, Burt BA, eds. Dentistry, dental practice and the community. 3rd ed. Philadelphia: WB Saunders, 1983:115-52.

3. Mansson B, Holm A-K, Ollinen I', Grahnen H. Dental health in 13-vear-old children in the north of Sweden-changes during a 10-year period. Swed Dent J 1979;3:193-203

4. McEniery TM, Davies GN. Brisbane dental survery 1977. A comparative study of caries experience of children in Brisbane, Australia over a $2(0)$-year period. Community Dent Oral Epidemiol 1979 Feb; 7:42-50)

5. Hugoson A, Koch G, Hallonsten A-L, Ludvigsson N, Lundgren D. Rvlander H. Dental health 1973 and 1978 in individuals aged 3-20 vears in the community of Jonkopping, Sweden. Swed Dent J 1980;150(4):217-29.

6. Anderson RJ. The changes in the dental health of 12-year-old schoolchildren in two Somerset schools. Br Dent J 1981 Apr;150:218-21

7. Anderson RJ. The changes in dental health of 12-vear-old schoolchildren resident in a naturally fluoridated area of Gloucestershire. Br Dent J 1981 June; 150:354-5.

8. Anderson RJ, Bradnock $G$, James PMC. The changes in the dental health of 12-year-old schoolchildren in Shropshire. $\mathrm{Br}$ Dent J 1981 Mav; 150:278-81.

9. Glass RL, Fleisch S. Decreases in caries prevalence. In: Hetferen I], Aver WA, Koehler HM, eds. Foods, nutrition and dental health. Volume 3. Park Forest South, 11l: Pathotox, 1981:181-90.

10. Milen A, Hausen H, Tala H, Paunio I, Heinonen OP. Caries in 35-year-old Finnish children participating in public dental care during 1974-79. Community Dent Oral Epidemiol 1981 Dec; 9:270-4.

11. Sheiham A. Changing trends in dental caries. Int J Epidemiol 1984 Jun; 13:142-7.

12. US Public Health Service. National Institute of Dental Research. The prevalence of dental caries in United States children, 197980. NIH pub no 82-2245. Washington DC: Government Printing Office, 1981.

13. Burt BA. The future of the caries decline. J Public Health Dent 1985 Fall;45:261-9.

14. Jackson D. Has the decline of dental caries in English children made water fluoridation both unnecessary and uneconomic? $\mathrm{Br}$ Dent J 1987 Mar;162:17)-3.

15. Dubos R. The mirage of health. New York: Doubleday, 1959.

16. Murray JJ. Appropriate use of fluorides for human health. Geneva: World Health Organization, 1986:41

17. Volpe AR. Dentifrices and mouthrinses. In: Stallard RE, ed. A textbook of preventive dentistry. 2nd ed. Philadelphia: WB Saunders, 1982:170-216.

18. Ericsson SY. Cariostatic mechanism of actions of fluorides: clinical ubservations. Caries Res [Suppl 1] 1977;11:2-23.

19. Horowitz HS. Cariostatic mechanism of fluorides: clinical observations. Caries Res [Suppl 1] 1977;11:22-34.

20. Dean HT, Arnold FA Jr, Jay P, Knutson JW. Studies on mass control of dental caries through fluoridation of the public water supply. Public Health Rep 1950 Oct;65: 1403-8.

21. McClure FJ, Likins RC. Fluorine in human teeth studied in relation to fluorine in the drinking water. J Dent Res 1951 Apr;30:172-6.

22. UK Ministry of Health. The fluoridation of domestic water supplies in North America as a means of controlling dental caries. London: Her Majesty's Stationery Office, 1953

23. McClure FJ. Fluoridation: the search and the victory. Bethesda, MD: NIH, 1970.

24. Russell AL, White CL. Dental caries in Maryland children after seven years of fluoridation. Public Health Rep 1961 Dec;76:108793.

25. Klein H. Dental caries in relocated children exposed to water containing fluorine. I. Incidence of new caries after 2 vears of exposure among previously caries-free permanent teeth. Public Health Rep 1945 Dec;60:1462-7.

26. Klein $\mathrm{H}$. Dental caries (DMF) experience in relocated children exposed to water containing fluorine. II. J Am Dent Assoc 1946 Sept;33:1136-41.
27. Ast DB, Chase HC. The Newburgh-Kingston caries fluorine study. IV. Dental findings after six years of fluoridation. Oral Surg 1953 Jan;6:114-23.

28. Arnold FA Jr, Dean HT, Knutson JW. Effect of fluoridated public water supplies on dental caries incidence. Results of the seventh year of study at Grand Rapids and Muskegon, Mich. Public Health Rep 1953 Feb;68:141-8.

29. Russell AL, Hamilton PM. Dental caries in permanent first molars after eight years of fluoridation. Arch Oral Biol 1961;6(Spec Suppl):50-57.

30. Russell AL, Elvove E. Domestic water and dental caries, VII. A study of the fluoride-dental caries relationship in an adult population. Public Health Rep 1951 Oct;66:1389-401.

31. Englander HR, Wallace DA. Effects of naturally fluoridated water on dental caries in adults. Public Health Rep 1962 Oct:77:88793.

32. Jackson D, Murray JJ, Fairpo CG. Life-long benefits of fluoride in drinking water. Br Dent J 1973 May;134:419-22

33. Brudevold F, Steadman LT, Smith FA. Inorganic and organic components of tooth structure. Ann NY Acad Sci $1960 \mathrm{Mar}$ 85:110-32.

34. Mellberg JR. Enamel tluoride and its anti-caries effects. J Prev Dent 1977 Jan-Feb;4:8-20.

35. Aasenden R, Allukian M, Brudevold F, Wellock WD. An in vivo study on enamel fluoride in children living in a fluoridated and in a nonfluoridated area. Arch Oral Biol 1971 Dec;16:1399-1411.

36. Aasenden R, Moreno EC, Brudevold F. Fluoride levels in the surface of different types of human teeth. Arch Oral Biol 1973 Nov; $18: 1403-10$

37. Aasenden R, Peebles TC. Effects of fluoride supplementation from birth on human deciduous and permanent teeth. Arch Oral Biol 1974 Apr;19:321-6.

38. Wefel JS. Mechanisms of action of fluorides. In: Stewart RE, Barber TK, Trotman KC, Wei SHY, eds. Pediatric dentistry. St Louis: CV Mosby, 1982:772-9.

39. Newbrun $\mathrm{E}$. Mechanisms of fluoride action in caries prevention. In. Newbrun E, ed. Fluorides and dental caries. Contemporary concepts for practitioners and students. Springfield, III: CC Thomas, 1986:155-73.

40. Nikiforuk G. Mechanism of cariostatic action of fluorides. Understanding dental caries 2. Prevention Basic and clinical aspects. Basel: Karger, 1985:45-62.

41. Young RA, van der Lugt W, Elliot JC. Mechanism for fluoride inhibition of diffusion in hydroxyapatite. Nature 1969 Aug;223:729-30.

42. van der Lugt $W$, Knottnerus DIM, Young RA. NMR determination of fluorine position in mineral hydroxyapatite. Caries Res 1970;4:89-95

43. Brudevold $F$. Chemical composition of the teeth in relation to caries. In: Sognnaes RF. Chemistry and the prevention of dental caries. Springfield, Ill: CC Thomas, 1962:32-88.

44. Nikiforuk G. Fluoride-carbonate relation in human dental enamel. Can Dent Ass J 1963 Apr;29:242.

45. Driessens FCM. Mineral aspects of dentistrv. In: Mvers HM, ed. Monograph in oral science 10. Basel, Switzerland: Karger, 1982.

46. Isaac S, Brudevold F, Smith FA, Gardner DE. The relation of fluoride in the drinking water to the distribution of fluoride in the enamel. J Dent Res 1958 Apr;37:318-25

47. Yoon SH, Brudevold F, Garner DE, Smith FA. Distribution of fluoride in teeth from areas with different levels of fluoride in the water supply. J Dent Res 1960 Jul-Aug;39:845-56.

48. Bruun C, Munksgaard EC, Stoltze K. A field biopsy method for fluoride determination in human enamel. Community Dental Oral Epidemiol 1975 Oct; 3:217-22

49. Mellberg JR, Singer L. Assimilation of fluoride by enamel through the life of the tooth. Caries Res [Suppl 1] 1977;11:101-15.

50. lijima $Y$, Katayama $T$. Fluoride concentration in deciduous enamel in high- and low-fluoride areas. Caries Res 1985; 19:2625

51. Driessens FCM. Relation between apatite solubility and anticariogenic effect of fluoride. Nature 1973 June;243:420-1

52. Moreno EC, Krezak M, Zahradnik RT. Fluoridated hydroxyapatite solubility and caries formation. Nature 1974 Jan;247:64-5

53. Newbrun E. Fluoride metabolism and mechanisms of action. In: Moss SJ, Wei SH, eds. Fluorides: an update for dental practice. New York: Medcom Inc, 1976:30-9.

54. Pearce EIF, Suckling GW, Cutress TW. Fluoride in the outer 
enamel of New Zealand children. 1. Its relation to the fluoride concentration of the water supply and to the use of fluoride tablets. NZ Dent J 1981 Oct;77:144-9.

55. Schamschula RG, Sugar E, Agus HM, Un PSH, Toth K. The fluoride content of human tooth enamel in relation to environmental exposure to fluoride. Aust Dent ] 1982 Aug;27:243-7.

56. Mellberg JR, Ripa LW, Leske GS. The relationship between dental caries and tooth enamel fluoride. Caries Res 1985:19:385-9.

57. Bruun C, Poulsen S, Ostergaard V. Hojbjerg R. Preeruptive acquisition of fluoride by surface enamel of permanent teeth after daily use of fluoride supplements. Caries Res 1983;17:8991.

58. Brown WE, Gregory TM, Chow LC. Effects of fluoride on thamel solubility and cariostasis. Caries Res [Suppl] 1977;11:118-41.

59. Levine RS. The action of fluoride in caries prevention; a review of current concepts. Br Dent J 1976 Jan;140:9-14

60. Aasenden R. Fluoride concentrations in the surface tooth enamel of young men and women. Arch Oral Biol 1974 Aug;19:697. 701 .

61. Keene HJ, Mellberg JR, Nicholson CR. History of fluoride, dental fluorosis and concentration of fluoride in surface laver of enamel of caries-free naval recruits. J Public Health Dent 1973 Summer; $33: 142-8$

62. Keene HI, Mellberg JR, Pederson ED. Relationship between dental caries experience and surface enamel fluoride concentra tion in young men from three optimally fluoridated cities. J Dent Res 1980 Nov; $59: 1941-5$

63. DePaola PF, Brudevold F, Aasenden R, Moreno EC, Englander H, Bakhos Y, Bookstein F, Warram J. A pilot study of the relationship between caries experience and surface enamel fluoride in man. Arch Oral Biol 1975 Dec;20:859-64

64. Pearce EIF, Suckling GW, Cutress TW. Fluoride in the outer enamel of New Zealand children. Il. Its relation to caries experience. NZ Dent J 1982 Jan;78:8-11.

65. Gedalia I, Rosenweig KA, Sadeh A. Fluoride content of superticial enamel layer and its correlation with fluoride content of saliva, tooth, age and DMFT count. J Dent Re's 1961 SepOct; $40: 865-9$.

66. Bischoff Jl, Van der Merwe EHM, Retief DH, Barkakow FH, Cleaton-Jones PE. Relationship between fluoride concentration in enamel DMFT index and degree of fluorosis in a community residing in an area with a high level of fluoride. J Dent Res 1976 Jan-Feb;55:37-42.

67. Poulsen S, Larsen MI. Dental caries in relation to fluoride content of enamel in the primary dentition. Caries Res 1975;9:59-65.

68. Englander HR, Mellberg JR. Failure to demonstrate an association between enamel fluoride concentration and dental caries in the deciduous dentition. J Dent Res 1976 Jul-Aug;55:707.

69. Richards A, Larsen MJ, Fejerskov O, Thylstrup A. Fluoride content of buccal surface enamel and its relation to dental caries in children. Arch Oral Biol 1977 Jul;22:425-8.

70. Shern RJ, Driscoll WS, Korts DC. Enamel biopsy results of children receiving fluoride tablets. J Am Dent Assoc 1977 Aug; $95: 310-4$.

71. Kidd EAM, Thylstrup A, Fejerskov O, Bruun C. Influence of fluoride in surface enamel and degree of dental fluorosis on caries development in vitro. Caries Res 1980;14:196-202.

72. Nasir HI, Retief DH, Jamison HC. Relationship between enamel fluoride concentration and dental caries in a selected population. Community Dent Oral Epdemiol 1985 Apr;13:65-7

73. Larsen MJ, Kirkegaard E, Poulsen S, Fejerskov O. Enamel fluoride, dental fluorosis and dental caries among immigrants to and permanent residents of five Danish fluoride areas. Caries Res 1986;20:349-55.

74. Driscoll WS, Heifetz SB, Brunelle JA. Caries preventive effects of fluoride tablets in schoolchildren tour years after discontinuities of treatments. J Am Dent Assoc 1981 Dec;103:878-81

75. Burt BA, Eklund SA, Loesche WJ. Dental benefits of limited exposure to fluoridated water in childhood. J Dent Res 1986 Nov:61:1322-5

76. Grainger RM, Coburn Cl. Dental caries of the first molars and the age of children when first consuming naturally fluoridated water. Can J Public Health 1955 Sept;46:347-54.

77. Russell AL. Dental effects of exposure to fluoride-bearing Dakota sandstone waters at various ages and for various lengths of time. Il. l'attern of dental caries inhibition as related to exposure span, to elapsed time since exposure, and to periods of calcification and eruption. J Dent Res 1949 Dec;28:600-12

78. Lemke CW, Doherty JM, Arra MC. Controlled fluorictation: the dental effects of discontinuities in Antigo, Wisconsin. I Am Dent Assoc 1970 Apr:80:782-6.

79. Hardwick JL, Teasdale J, Bloodworth G. Caries increments over 4 years in children aged 12 at the start of water fluoridation. $\mathrm{Br}$ Dent J 1982 Sept;153:217-22.

80. Thylstrup A, Fejerskov O, Bruun C, Kann J. Enamel changes and dental caries in 7-vear-old children given fluoride tablets from shortly after birth. Caries Res 1979;13:265-76.

81. Fejerskov O. Thylstrup A, Larsen MI. Rational use of fluoride in caries prevention; a concept based on possible cariostatic mechanisms. Acta Odont Scand 1981:39:241-9.

82. Bruun C. Thylstrup A. Fluoride in whole saliva and dental caries experience in areas with high or low concentrations of fluoride in the drinking water. Caries Re's 1984;18:450-6.

83. Fejerskov $\mathcal{O}$. Fluoride and enamel. Summary of session and panel discussion. In. Guggenheim B, ed. Cariology today. Basel: Karger, 1984:362-74.

84. Arends J, Gelhard TBFM. In vivo remineralization of human enamel. In: Edgar WM, Leach SA, eds. Demineralization and remineralization of the teeth. Oxford: IRL P'ress, 1983:1-16.

85. Koulourides T, Feagin F, Pigman W. Remineralization of dental enamel by saliva in vitro. Ann NY Acad Sci 1965;131:751-7.

86. Kleinberg 1, Chatterju R, Denepitiva L. Effects of salivia and dietary eating habits on the $\mathrm{pH}$ and demineralisation-remine ralisation potential of dental plaque. In: Leach SA, Edgar WM. eds Demineralisation and remineralisation of the teeth. Oxford: IRI Press, 1983:25-50

87. Leach SA, Agalamanyi EA, Green RM. Remineralization of the teeth by dietary means. In: Leach SA, Edgard WM, eds. Demineralisation and remineralisation of the teeth. Oxtord: IRL Press, 1983:51-73

88. Backer Dirks O. Posteruptive changes in dental enamel. J Dent Res [Suppl 3| 1966 Mari45:503-1]

89. Backer Dirks $O$. The relation between the fluoridation of wiater and dental caries experience. Int Dent J 1967 Sept;17:582-605.

90. von der Fehr FR, Löe H, Theilade E. Experimental caries in man Caries Res 1970;4:131-48.

91. Little MF, Casciani FS, Rowley J. Site of fluoride dccumulation in intact erupted human enamei. Caries Res 1969;3:109-18

92. Hallsworth AS, Weatherell JA. The microdistribution uptake and loss of fluoride in human enamel. Caries Re's 1969;3:109-18

93. Weatherell JA, Deutsch D, Robinson C, Hallsworth AS. Assimilation of fluoride by enamel throughout the life of the tooth. Caries Res [Suppl 1| 1977;11:85-101.

94. Koulourides T, Keller SE, Manson-Hing L, Lilley V. Enhancement of fluoride effectiveness by experimental cariogenic priming of human enamel Caries Res 1980;14:32-9.

95. Koulourides T, Cameron B. Enamel remineralization as a factor in the pathogenesis of dental caries. J Oral Pathol 1980 Sept; $9: 255-69$.

96. Koulourides T, Cueto H, Pigman W. Rehardening of softented enamel surfaces of human teeth by solutions of calcium phos phates. Nature 1961 Jan:189:226-27.

97. Koulourides T, Feagin F, Pigman W. Effect of pH, ionic strength, and cupric ions on the rehardening rate of buffer-softened human enamel. Arch Oral Biol 1968 Mar; 13:335-41.

98. ten Cate JM, Arends J. Remineralization of artificial enamel lesions in vitro. Carie's Res 1977;11:277-86.

99. Silverstone LM, Wefel JS, Zimmerman BF, Clarkson BII, Featherstone MJ. Remineralization of natural and artificial le'sions in human dental enamel in vitro. Effect of calcium concentration of the calcifying fluid. Caries Res 1981;15:138-57

100. Featherstone JDB. Remineralization of artificial carious lesions in vivo and in vitro. In: Leach SA, Edgar WM, eds. Demineralisation and remineralisation of the teeth. Oxford: IRL Press. 1983;89-110.

101. Silverstone LM. Remineralization phenomena. Cariess Res [Suppl 1] 1977;11:59-79.

102. Silverstone LM. Experimental caries models and their clinical implications. In: Guggenheim B, ed. Cariologry todav. Basel. Karger, 1984:237-44 
103. Silverstone LM. Fluorides and remineralization. In: Clinical uses of fluorides. Wei SHY, ed. Philadelphia: Lea \& Febiger, 1985:15375

104. Gelhard T, Ten Cate J, Arends J. Rehardening of artificial enamel lesions in vivo. Caries Res 1979;13:80-3.

105. Featherstone JDB, Cutress TW, Rodgers BW, Dennison PJ. Remineralization of artificial caries-like lesions in vivo by the selfadministered mouthrinse or paste. Caries Res 1982;16:235-42.

106. Dijkman AG, Schuthof J, Arends J. In vivo remineralization of plaque-induced initial enamel lesions-a microradiographic investigation. Caries Res 1986;20:202-8

107. Corpron RE, More FG, Clark JW, Korytnicki D, Kowalski CJ. In vivo remineralization of artificial enamel lesions by a fluoride dentifrice or mouthrinse. Caries Res 1986;20:48-55.

108. Clark JW, More FG, Corpron RE, Korytnicki D, Kowalski CH Effects on artificial enamel lesion in vivo by exposure to $\mathrm{NaF}$ lozenges. Caries Res 1986;20:465-72.

109. Featherstone JDB. Diffusion phenomena and enamel caries development. In: Guggenheim B, ed. Cariology Today. Basel: Karger, 1984:259-68.

110. Jenkins GN, Edgar WM, Ferguson DB. The distribution and metabolic effect of human plaque fluorine. Arch Oral Biol 1969;14:105-19.

111. Thylstrup A, Bille J, Bruun C. Caries prevalence in Danish children living in areas with low and optimal levels of natural water fluoride. Caries Res 1982;16:413-20.

112. Johnston DW, Grainger RM, Ryan RK. The decline in dental caries in Ontario schoolchildren. Can Dent Assoc J 1986 May 5:411-7.

113. Brunelle JA, Miller AJ, Smith JI. DMFS in US children with and without lifelong exposure to water fluoridation [Abstract]. J Dent Res 1983;62(Spec Iss):203.

114. Kohler B, Bratthall D. Intrafamilial levels of Streptococots mutans and some aspects of the bacterial transmission. Scand J Dent Res 1978 Jan; $86: 35-42$.

115. Kohler B, Bratthall D, Krasse B. Preventive measures in mothers influence the establishment of the bacterium Streptococus mutams in their infants. Arch Oral Biol 1983 Mar;28:225-31.

116. Kohler B, Andreen I, Jonsson B. The effect of caries-preventive measures in mothers on dental caries and the oral presence of the bacteria Streptococis mutans and lactobacilli in their children. Arch Oral Biol 1984 Nov;29:879-83.

117. Rosen S, Frea JI, Hsu SM. Effect of fluoride-resistant microorganisms on dental caries. J Dent Res 1978 Feb;57:180.

118. Bowden GW, Odlum O, Nolette N, Hamilton IR. Microbial populations growing in the presence of fluoride at low $\mathrm{pH}$ isolated from dental plaque in children living in an area with fluoridated water. Infect Immun 1982 Apr;36:247-54.

119. Klock B, Krasse B. Caries status and microbial conditions in children today and 12 years ago [Abstract]. J Dent Res 1985;65 (Spec Iss): 209.

120. Loesche WJ. Topical fluorides as an antibacterial agent. J Prev Dent 1977 Jan-Feb; 4:21-6

121. Peterson JK. A supervised brushing trial of sodium monofluorophosphate dentifrices in a fluoridated area. Caries Res 1979;13:68-72.

122. Zacherl WA, Long DM. Reduction in caries attack rate-nonfluoridated community [Abstract]. J Dent Res 1979 Jan; 58 (Spec Iss A): 227 .

123. Backman B, Crossner CG, Holm A-K. Reduction of caries in 8year-old Swedish children between 1967 and 1979. Community Dent Oral Epidemiol 1982 Aug;10:178-81.

124. Bristow PD, Humpherson WA, Minton OH, Tucker GH, Weedon AF. South-west Thames region dental survey. Br Dent J 1982 Aug; 153:148-9.

125. Bryan ET, Collier DR, Howard WR, VanCleave ML. Dental health status of children in Tennessee-a 25-year comparison. I Tenn Dent Assoc 1982 Jan;61:31-3.

126. Carr LM. Dental health of children in Australia 1977-80. Aust Dent J 1982 Jun;27:169-75.

127. Latcham NL, Powell RN, Jago JD, Sevmour GJ, Aitken JF Changes in proximal caries status of Brisbane 15-year-old children over a ten-year period. Aust Dent J 1982 Dec;27:357-9

128. Silver DH. Improvements in the dental health of 3-vear-old Hertfordshire children after 8 years. The relationship to social class. Br Dent J 1982 Sept;153:179-83.

129. Fejerskov O, Antoft P, Gadegaard E. Decrease in caries experience in Danish children and young adults in the $1970^{\prime} \mathrm{s}$. J Dent Res 1982 Nov;61 (Spec Iss):1305-10.

130. O'Mullane DM. The changing patterns of dental caries in Irish schoolchildren between 1961 and 1981. J Dent Res 1982 Nov;61 (Spec Iss):1317-20.

131. Kalsbeek H. Evidence of decrease in prevalence of dental caries in the Netherlands: an evaluation of epidemiological caries surveys on 4-6 and 11-15-year-old children, performed between 1965 and 1980. J Dent Res 1982 Nov;61 (Spec Iss): 1321-6.

132. Brown RH. Evidence of decrease in the prevalence of dental caries in New Zealand. J Dent Res 1982 Nov;61 (Spec lss): 1327 30 .

133. von der Fehr FR. Evidence of decreasing caries prevalence in Norway. J Dent REs 1982 Nov;61 (Spec Iss):1331-5.

134. Glass RL. Secular changes in caries prevalence in two Massachusetts towns. J Dent Res 1982 Nov;61 (Spec Iss):1352-5.

135. DePaola PF, Soparkar PM, Tavares M, Allukian M Jr, Peterson H. A dental survey of Massachusetts schoolchildren. J Dent Res 1982 Nov;61 (Spec Iss):1356-60.

136. Allen CD, Ashley FP, Naylor MN. Caries experience in 11 -yearold schoolgirls between 1962 and 1981; a radiological study. Br Dent J 1983 Mar;154:167-70.

137. Clerehugh V, Blinkhorn AS, Downer MC, Hodge 1 IC, RuggGunn AJ, Mitropoulos CM, Worthington HV. Change's in the caries prevalence of 11-12-vear-old schoolchildren in the northwest of England from 1968 to 1981 . Community Dent Oral Epidemiol 1983 Dec;11:367-70.

138. Hargreaves JA, Thompson GW, Wagg BJ. Changes in caries prevalence of Isle of Lewis children between 1971 and 1981 Caries Res 1983;17:554-9.

139. Hausen $H$, Milen A, Tala $H$, Nordling H, Paunio I, Heinonen OP. Caries frequency among 6-17-year-old participants of the Finnish public dental care during 1975-79. Community Dent Oral Epidemiol 1983 Feb;11:74-80.

140. Sposato AL, Leske GS, Ripa LW. The changing dental care patterns of participants in a school-based fluoride mouthrinsing program. Pediatr Dent 1983 Mar;5:53-6.

141. Hanzely B, Banoczy J, Hadas E, Esztari I, Nemes J, Albrecht M, Valkovics M. Caries prevalence of preschool children in Baja Hungary, in 1975 and 1982: effect of a supervised monthly NaF mouthrinsing program. Community Dent Oral Epidemiol 1985 Aug;13;230-4.

142. Møller P. Caries prevalence in Icelandic children in 1970 and 1983. Community Dent Oral Epidemiol 1985 Aug;13:230-4.

143. Stookey GK, Sergent JW, Park KK, Jackson RD, Drook CA Prevalence of dental caries in Indiana schoolchildren; results of 1982 survey. Pediatr Dent 1985 Mar;7:8-13.

144. Truin G-J, Konig KG, Ruiken RMHM, Plasschaert AJM, Vogels ALM. Dental caries and gingivitis in second grade schoolchildren in The Hague over the period 1969-1981. Community Dent Oral Epidemiol 1985 Dec;13:319-22.

145. Mansbridge JN, Brown MD. Changes in dental caries prevalence in Ayr children over 25 years and a comparison with Edinburgh children over the same period. Community Dent Health 1986 Mar;3:41-52. 